\title{
Doctor Jean-Paul Marat (1743-93) and his time as a physician in Great Britain
}

\author{
${ }^{1}$ JR Silver, ${ }^{2} \mathrm{M}-\mathrm{F}$ Weiner \\ ${ }^{1}$ Retired Consultant in Spinal Injuries and Fellow of the Institute of Sports Medicine; ${ }^{2}$ Research Associate and MA History of Medicine \\ Graduate Oxford Brookes University, Oxford, UK
}

\begin{abstract}
Jean-Paul Marat was a French revolutionary, famously murdered in his bath by Charlotte Corday in 1793. A lesser known fact is that for over ten years he lived in Britain where he practised as a doctor. During this time he visited London, Edinburgh, Dublin and Holland. Although he had no formal medical training, he published two medical papers on gleets (gonorrhoea) and diseases of the eyes and, on the recommendation of two eminent Scottish physicians, William Buchan and Hugh James, he was granted a medical degree from the University of St Andrews. Marat left no medical legacy and his related writings were forgotten for 100 years until the rediscovery of the two medical papers, which were eventually re-published in 1892 at the instigation of James Bailey, the librarian of the Royal College of Surgeons of England. Biographies by F Chevremont (I880), Ashbee Spencer (1890) and A Cabanès (I89I) had rekindled interest in this intriguing revolutionary. A study of his time in Britain and his medical works and training provide an interesting insight into the mind of a revolutionary and how his sojourn may have shaped his future political career upon his return to France in 1777.
\end{abstract}

\author{
Correspondence to JR Silver \\ 8 High Street \\ Wendover, Buckinghamshire \\ HP22 6EA, UK
}

tel. +44 (0) I296 623013

e-mail jrussellsilver@btconnect.com

KEYWORDS Jean-Paul Marat, gleets, diseases of the eyes, French Revolution

DECLARATIONS OF INTERESTS No conflicts of interest declared.

Jean-Paul Marat is best known as a French revolutionary and for being murdered in his bath by Charlotte Corday in 1793, a scene immortalised by Jacques Louis David's painting (Figure I). Less well known is Marat's other career as a physician and scientist. He spent over ten years in Britain between 1765 and 1776, during which time he practised as a physician in London and Edinburgh. This article explores the lesser-known Marat, his medical career and his contribution to medical science.

During the French Revolution, Marat was described as 'a tiger that would have drunk the blood of his mother from the skull of his father' but also as 'the friend of the people'.' An objective account of his medical career however has been elusive and related literature spanning the period 1796 to 2004 is both subjective and full of contradictions about his medical credentials, his medical career both in France and in Britain, and his scientific legacy.

\section{LITERATURE REVIEW}

Contemporaneous literature reveals little of Marat's medical career. In his memoirs, published posthumously in 1830, Jean Paul Brissot, a pro-revolution French political journalist, gave an account of his encounter with Marat in London and described his medical career. His views however are tainted by a rift between the two men. ${ }^{2}$ Marat's own writings in L'Ami du Peuple (a newspaper established to advocate the rights of the

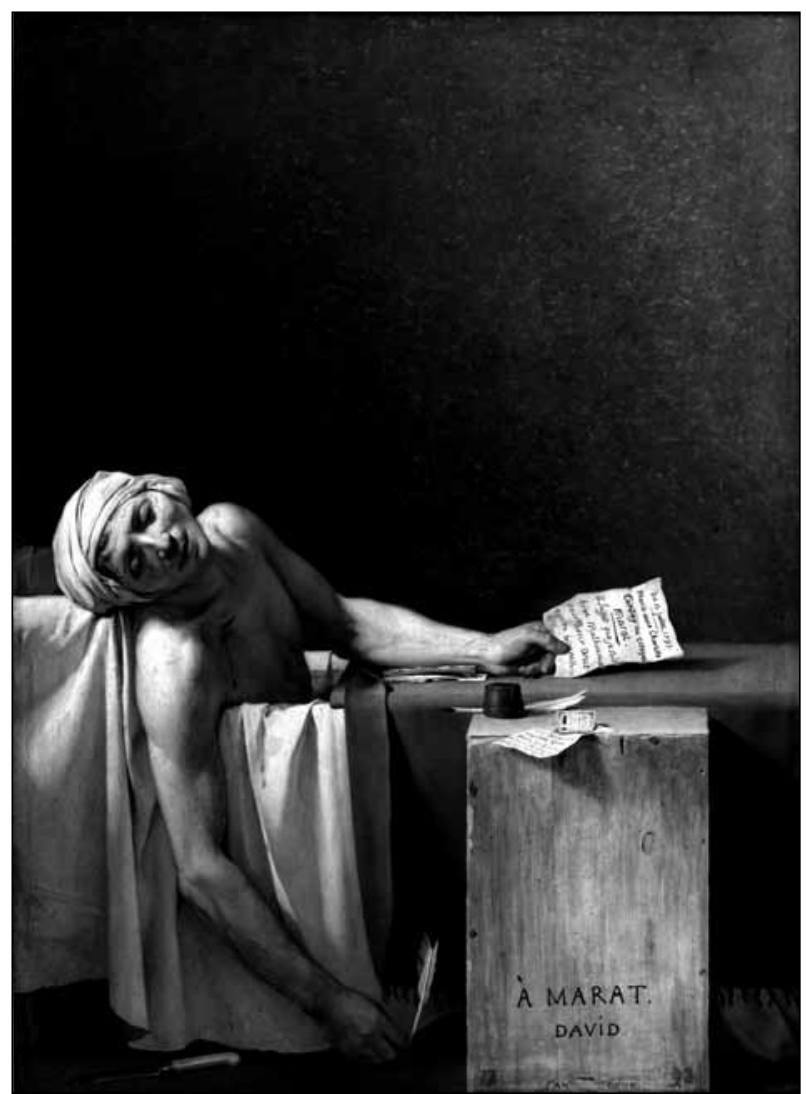

FIGURE I Jacques-Louis David: 'The assassination of Marat'. Photographer:J Geleyns (copyright: Royal Museums of Fine Arts of Belgium, Brussels). 
lower classes) give an insight into his early life and his political thinking, although anything written by Marat about himself should be independently verified as it is vague, at times inconsistent and there are concerns about its reliability. ${ }^{3}$ On his return to France in 1777 , Marat published a much lauded memoir on 'medical electricity' for which he was awarded a prize from the Royal Academy of Science in Paris in 1783, but this very technical document does not yield any further information about his time in Britain. ${ }^{4}$ The only factual evidence from this time are his two scientific papers on gleets and diseases of the eye and the transcript of his diploma from St Andrews University. ${ }^{5-7}$

In 1882, Stephens described Marat's work on diseases of the eyes (1776) as 'the lost medical work of Marat'. ${ }^{8}$ It was thought to be 'the only known copy of a medical tract written by Jean-Paul Marat during the time he was in practice in Church Street Soho', ${ }^{8}$ and was held at the Royal Medical and Chirurgical Society of London. But it was the subsequent discovery of a rare copy of Marat's previous work on the treatment of gleets, dated I775, which prompted James Bailey, librarian to the Royal College of Surgeons of England to seek permission to reproduce both in one volume entitled Marat in England.? The paper on gleets had come into the possession of $\mathrm{Dr}$ JF Payne, medical historian and librarian of the Royal College of Physicians of London. ${ }^{10}$ Both papers and their prefaces form the basis of most of Bailey and Stephens's assertions about Marat's medical career in London and, while there are still uncertainties, they

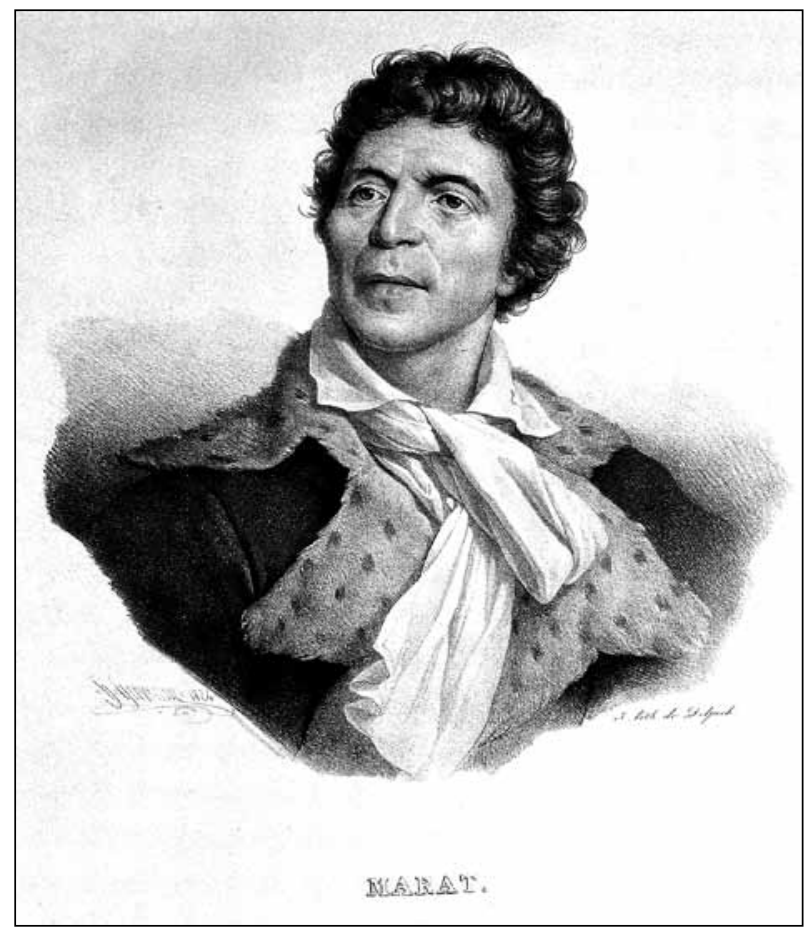

FIGURE 2 Jean Paul Marat. Lithograph by H Grévedon, 1824, after J Boze, 1793. Reproduced by kind permission of the Wellcome Library, London. have interpreted the primary evidence rigorously. Indeed in his introduction to the re-publication, Bailey describes how errors have not been corrected and the papers were reproduced exactly as Marat wrote them. ${ }^{10}$

Current historians have revisited Marat's medical career ${ }^{9,11-13}$ but recent accounts on Marat are divided. Conner, a European historian at City University of New York, provides a favourable and pro-revolutionary account while Gillispie, a science historian and specialist on the Revolutionary and Napoleonic periods, offers a more balanced view, although the scientific basis upon which he describes Marat's two papers as 'clear and creditable medical papers' is unclear. ${ }^{11,12}$ Gillispie remarked that 'reactions to Marat are a touchstone of feelings about the French Revolution in all its inwardness'."

A man who can engender such extreme reactions merits further investigation and this study of the significance of Marat's medical work was carried out to assess his medical legacy.

\section{MARAT'S UPBRINGING AND MEDICAL TRAINING}

Marat was born on 24 May 1743 in Boudry near Neuchâtel, Switzerland, into a middle class family of Spanish origin (Figure 2). His father gave up the priesthood to become a designer and language teacher and he enthusiastically imparted knowledge to his children. The young Marat mastered five European languages and obtained a firm grounding in science. ${ }^{14}$ ' was unusually fortunate to receive a very sound education from my father' he claimed, yet he regretted that 'his only desire was to make me a learned man'..5

In 1759, at the age of 16, Marat showed an early interest in science when he applied to join a government sponsored astronomical expedition to Tobolsk to observe a transit of Venus, but his application was unsuccessful. ${ }^{16} \mathrm{He}$ resolved instead to become a teacher and left home to be a tutor to M. Nayrac's children in Bordeaux where he stayed for two or three years. ${ }^{17}$ Between 176I and 1765, Marat studied in Bordeaux and Toulouse and then in Paris. How Marat obtained his medical training remains a mystery. Medical training was still not formalised and the necessary knowledge could be obtained through a university degree, by studying under a 'master' such as Boerhaave, or by apprenticeship. Marat did none of these. As was the practice elsewhere in Europe, he attended private courses in medicine and physics as well as politics and literature. ${ }^{2} \mathrm{He}$ may have attended lectures, although there are no records of his enrolment at a university. The founding of a Royal Academy of Surgery in Paris in 1748 and the recognition of the long established courses at Saint Côme as an official College of Surgery resulted in a renaissance of the teaching of anatomy in the city. ${ }^{18}$ State medical 
education only came about after 1794 in France, when the Convention accepted Fourcroy's 'New Plan for Medical Education' and three new 'Schools of Health' were set up in Paris, Strasbourg and Montpellier.'

\section{MARAT'S TIME IN BRITAIN I765-76}

The reason Marat came to Britain, like much of his life, is shrouded in mystery. Marat claimed that he wanted to complete his medical training. Conner wrote that Marat saw Britain as 'the last refuge of freedom', in contrast to despotic France. ${ }^{12}$ Gillispie suggested that he had already faced the ire of the French Establishment and came to Britain to 'avoid dissipation and learn more about science'." There is no evidence that he attended the Hunters' School of Anatomy in London. Marat's own account of this time is vague, yet in 1775 he refers to his ten years of medical practice, which implies that he started practising in 1765, the year of his arrival in Britain. He had a dispensary in Church Street, Soho, the French quarter of London. Marat became a wellestablished London physician, although without a licence to practise from the Royal Colleges. The Royal College of Physicians of London only granted membership to graduates from the Universities of Oxford and Cambridge (although graduates from other universities could become licensees) and 'unqualified' practitioners were actively pursued. ${ }^{20}$ Marat socialised with various foreign artists including the Venetian painter, Antonio Zucchi and Angelica Kauffmann, with whom he reputedly had an affair. ${ }^{2}$ Becoming a member of Soho's Masonic lodge in 1774 would have further extended Marat's social circle and influence."

\section{THE QUALIFICATION CONTROVERSY - ACCUSATIONS OF CHARLATANISM}

In 1774 Marat visited Scotland, but there are very few details of his stay. He may have spent a year there but there is no information on his medical practice in Edinburgh apart from the observation that he worked with Mr Miller, an oculist.' ${ }^{13}$ The following year, two eminent Edinburgh doctors, William Buchan and Hugh James recommended Marat for the award of an MD from St Andrews University by signing a certificate of competence. Without having to attend the university and on payment of a graduation fee, Marat was granted the degree of Doctor of Medicine on 30 June 1775, ten years after arriving in Britain. ${ }^{12}$ The transcript of the diploma refers to Marat's many years of practice as a doctor in all the branches of medicine and his great skill. ${ }^{14}$ Phipson, a barrister, accused Marat of 'buying' his degree, claiming that this was the means by which $\mathrm{St}$ Andrews University raised much needed funds. He also asserted that Buchan was returning a favour as Marat had translated his book, Domestic Medicine, published in 1767, into French. ${ }^{21}$ The awarding of degrees in this manner was common practice at the time in St Andrews as it was difficult to gain a doctorate elsewhere in Great Britain. The universities of Oxford and Cambridge did award degrees but only to Anglicans. The contemporary medical historian John Blair, himself a graduate of $\mathrm{St}$ Andrews, has made a detailed analysis of the St Andrews MD. The controversy rested on the fact that the university had no medical school, degrees could be purchased without an examination, awarded in absentia and the professors of medicine were appointed through nepotism. As a result, the degrees were viewed with scorn by the leading anatomist and surgeon John Hunter (1728-93), the Royal College of Physicians of London and the Courts in England. ${ }^{5}$ Interestingly, despite having obtained his MD from St Andrews Marat described himself as 'JP Marat, MD London' in his work. In I774, Marat also went to Holland but no information about his medical career there has been found. Apart from his two publications and his degree, there are few hard facts about his career in London. Various writers have suggested in diaries or biographies that he was a fashionable physician and he was treating venereal disease but there is no substantive evidence. ${ }^{2,11,14}$

\section{MARAT'S PUBLICATIONS}

Marat's early writings, An Essay on the Human Soul (1772) and A Philosophical Essay on Man (1773) were published anonymously and subsequently attributed to him. He waited ten years before 'regularising' his position as a doctor in Britain. It is significant that his paper on gleets, dated 17 November 1775, officially presented to the Company of Surgeons of London, is the first publication for which he claimed authorship, a recognition of his 'regularised' status among the profession. In his article in L'Ami du Peuple in 1793, Marat stated the importance of medical education. He also referred to the 'few years when he consecrated his time to practising medicine'. ${ }^{3}$

\section{An Essay on Gleets}

Marat dedicated this work on gonorrhoea to the Company of Surgeons of London because surgeons were involved extensively in the treatment of venereal disease. Professor Bynum from University College London, has shown how venereal diseases offered a lucrative field and attracted physicians, surgeons and quacks alike. ${ }^{22}$ Despite his apologetic claim of being insufficiently conversant with the English language, Marat's writing is fluent. Bayon, a medical historian, notes that Marat mentions in a footnote on the first page that 'if his essay should meet with approbation, he would offer to the public a new method of radically curing gonorrhoea in a short time.' The paper described existing methods of treating gleets by means of 'bougies' long thin probes imbibed with 'irritating' substances such as oils and herbal preparations and inserted into the urethra to cause inflammation and encourage suppuration. This method is described in detail in Hunter's book on venereal diseases. ${ }^{23}$ Bayon mentions that Marat used the bougie method, introduced by 
Jacques Daran, but that he applied different bougies according to the stage of infection believing this to be a more refined treatment.' Marat explained how important it was to adapt the treatment to the severity of the condition, carefully identifying the 'seat of the disease' to direct treatment appropriately. He warned against the use of oil, contending that this adversely affected the healing of ulcers. He avoided 'desiccative' bougies which, because they had dried out, would result in scarring and urethral stricture leading to difficulties in passing urine, a common complication of gonococcal infection. The main difference with his approach was that he used milder irritants on a more selective area and decreased the strength of the treatment as the condition improved. $\mathrm{He}$ corroborated his findings with two detailed case studies of patients previously unsuccessfully treated by others to whom he applied his method to effect a cure. Marat's confidence in his ability to cure gleets is evident in his final remark: 'There is no gleet incurable: there is none which cannot easily and speedily be cured if properly treated'. ${ }^{6}$ This confident assertion is however not borne out by the nature of the illness, and even today chronic venereal discharges can be very resistant to treatment.

\section{An Enquiry into the Nature, Cause and Cure of a Singular Disease of the Eyes}

Marat's interest in diseases of the eyes ${ }^{7}$ may have been as a result of his working with an oculist in Edinburgh. His research was presented to the Royal Society in London in 1776. When Marat's widow, Simmone Evrard, republished his political writings from L'Ami du Peuple in 1790, she wrote that Marat had become very famous for his treatment of ailments of the eyes. ${ }^{8}$

This paper is grammatically well written but the scientific data were incomprehensible to a modern consultant ophthalmologist (S Davidson, Nov 9 20I I). In contrast to his earlier work, re-examination in the light of current knowledge does not allow for a meaningful diagnosis, as the description of the symptoms and the clinical details are so incomplete and difficult to understand. There are various possibilities for the condition he describes: it could be an acute uveitis, acute glaucoma, a chronic discharge from gonorrhoea, a cellulitis, or a myopathy. All of these possible diagnoses are purely speculative. Marat describes three cases referred to him after they had already received treatment with mercury. He claimed that they were misdiagnosed as gutta serena (failing eyesight) instead of gutta opaca or cataract with blurred vision. He claimed that the diagnosis had been made by a friar with a good reputation for curing diseases of the eye. Writing in 1945, Bayon, a qualified doctor and medical historian, believed that the connection between mercurial treatment and this ophthalmia could not be established.' Marat suggested that the cause might have been swelling of the ocular muscles, influencing the curving of the lens and resulting in a lack of accommodation. Multiple treatments were applied, making it impossible to determine what the patient actually received. Bayon stated that the patient did not show the features of mercury poisoning. Fascinatingly, although an effective treatment for scurvy had only been described by Lind in 1753, Marat also treated the third case with antiscorbutic remedies. ${ }^{24}$ Notwithstanding the fact that the patient had not received enough mercury to poison him, all the other drugs could well have done so.

The 'electric' treatment applied by Marat seemingly resulted in considerable improvement, but Bayon could not identify any lasting improvement in the course of the disease and suggested that this might have been a placebo effect.' Although Marat's paper gives a fascinating insight into medicine at the time, the clinical data, at best, can only give rise to speculation as to the true nature of the condition or conditions being described.

Marat's paper on gleets did not have a big impact at the time of publication and whereas similar papers by John Hunter and Jacques Daran are referred to in the literature,Marat's was forgotten. When the contemporary medical historian William Bynum wrote a survey on the history of the treatment of venereal diseases in 1987, he did not cite Marat's paper. ${ }^{22}$ Marat's work on diseases of the eyes has little medical merit and had it not been for his subsequent political career, it too would likely have been ignored. They both lay forgotten for over 100 years and were only reprinted in 1893 through the efforts of James Bailey, when Marat's latter notoriety attracted attention to his previous medical career. ${ }^{25}$ Marat left no medical legacy and his career as a doctor is of little consequence. Nevertheless, Marat's approach to patients was ahead of his time; he examined his patients face to face, asking precise questions to guide his diagnosis and he respected patients' anonymity, referring to them by their initials in his scientific publications.

\section{RETURN TO FRANCE}

In 1777, Marat returned to France and practised as a doctor in Paris where he became known as 'doctor to the incurables', a sobriquet given to him after he cured consumptive patients and patients suffering from venereal diseases, about which he claimed that 'there is no gleet incurable'. ${ }^{6}$ In May 1777, he was called to treat the Marquise de Laubespine who suffered from pulmonary tuberculosis. He prescribed a secret remedy famously known as 'l'eau pulmonaire du Dr Marat' and she made a successful recovery and was considered to have been cured (Bayon ascribed the recovery to a temporary remission which can occur with tuberculosis of the lungs). 'To express her gratitude, she recommended Marat to the Comte d'Artois, the King's brother, who appointed him as 'Medecin du Corps des Gardes'. ${ }^{14}$ In 1783, he tried unsuccessfully to secure a position at the newly formed Royal Medical Academy in Madrid, claiming that his medical practice in Paris had suffered as a result of professional jealousies. 


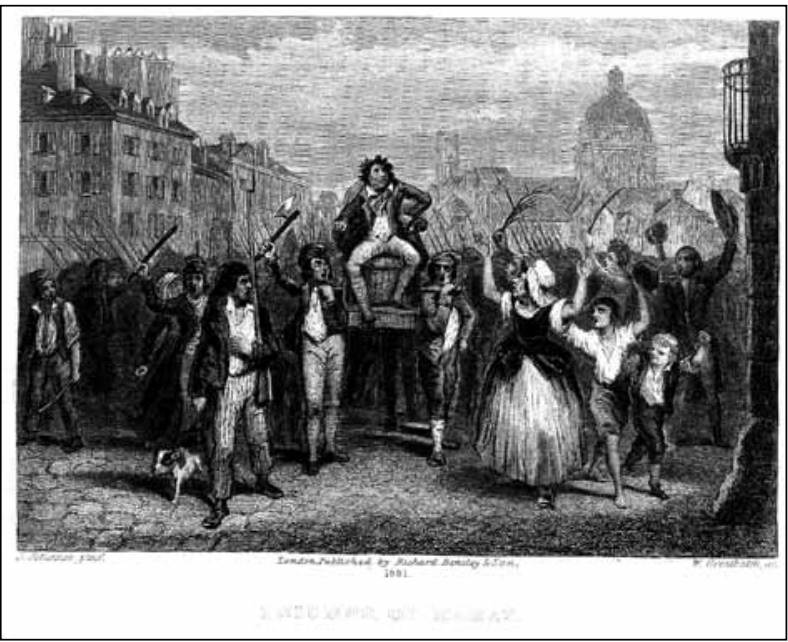

FIGURE 3 Engraving: 'Triumph of Marat'; by W Greatbatch after Tony Johannot, 188I. Reproduced by kind permission of the Wellcome Library, London.

His last medical publication was his memoir on the medical use of electricity, published in 1783, for which he was awarded a medal by the Royal Academy of Sciences and Arts of Rouen. ${ }^{4}$ Marat's focus then changed from medicine to physics (although he had published his famous monograph on fire, electricity and light in 1778). ${ }^{26} \mathrm{He}$ became an autodidact in the sciences of optics and electricity. He tried unsuccessfully to obtain recognition from the Academy, although they finally reconsidered his memoir and after six months awarded him a prize and offered him membership of the Academy, which he declined. ${ }^{15}$

During his stay in Britain, Marat had not attracted controversy; he adopted an almost obsequious and humble tone in his writing. On his return to France however, he became belligerent and politically engaged. He quickly published articles in L'Ami du Peuple and started voicing his political views openly, criticising Voltaire and Newton, which inevitably brought him into conflict with the Establishment. Marat had set himself on the path of a revolutionary and his behaviour here was in striking contrast to that in Britain (Figure 3).

\section{REFERENCES}

I Bayon HP.The medical career of Jean-Paul Marat. Proc R Soc Med 1945; 39:39-45.

2 Brissot JP. Mémoires de Brissot sur ses contemporains, et la Révolution Française. Paris: MF de Montrol; 1830. French.

3 SNOF.org [Internet]. Strasbourg: Encyclopédie de la vue [cited 2012 Dec 18]. Available from: http://www.snof.org/histoire/marat.html

4 Marat JP. Mémoire sur l'electricité médicale. Paris: De l'imprimerie de L Jorry; I784. French.

5 Blair JSG. The history of medicine in the University of St Andrews. Edinburgh: Scottish Academic Press; 1987. p.23-38.

6 Marat JP. An essay on gleets: wherein the defects of the actual method of treating those complaints of the urethra are pointed out, and an effectual way of curing them indicated. London: W Nicholl and J Williams; 1775.

\section{MARAT'S LEGACY}

Marat has been compared to Lenin, and described as a charismatic man, able to convince people and command attention. ${ }^{27}$ Despite an unprepossessing appearance and a debilitating skin complaint, Marat was successful with women. ${ }^{28} \mathrm{His}$ circle of friends and acquaintances before coming to Britain is not documented. Although untrained, by force of personality and intellect alone he impressed many people in Britain, Holland and France: John Wilkes, the parliamentarian who became Mayor of London in 1774; William Buchan and Hugh James, during his stay in Edinburgh; in Holland, Marat made the acquaintance of Rijklof Michael van Goens, a respected intellectual leader and supporter of the house of Orange. ${ }^{12}$ Benjamin Franklin and the French academician Le Roy praised Marat's work on light.

Marat had an ambivalent relationship with the Establishment, seemingly rejecting it while also seeking recognition and acclaim. Marat unquestionably valued his medical education, saying that: 'Whilst one cannot acquire the genius of Esculape, this provides knowledge which prevents us from acting blind and, under the eye of a master of the art, students learn to use their knowledge in a clear manner, not available to the empiricists. ${ }^{3}$ His principles and medical training guided his approach in medicine and politics. However, despite his experiences and intellectual labours, Marat left no medical legacy. Like other outsiders, he was rejected by the Ancien Régime and set out to destroy it.

\section{Acknowledgements}

We are grateful for the help we received from Professor William Bynum and Mr Sydney Davidson and we thank the Wellcome Library for permission to reproduce the illustrations.
7 Marat JP. An enquiry into the nature and cure of a singular disease of the eyes. London:W Nicholl and J Williams; 1776.

8 Stephens AM. The lost medical work of Marat. The Academy 1882; 542:225.

9 Bailey JB.A lost book by Marat. The Academy 1891; 106:57-8.

10 Marat JP. Medical tracts. London: Percival and Co; 1892.

II Gillispie CC. Scientists and charlatans. In: Science and polity in France: the end of the old regime. Princeton, New Jersey: Princeton University Press; 2004. pp.290, 293, 298, 316.

12 Conner CD. Jean Paul Marat: scientist and revolutionary. New York: Humanity Books; 1999. pp. 18, 20, 22, 33, 43.

13 Nockels K.Jean Paul Marat (1743-1793):scientist and revolutionary. J Med Biog 1994; 2:156-61.

14 Cabanès A. Marat inconnu. L'Homme privé, le médecin, le savant. Paris: Léon Genonceaux; 1891. pp.43, 54, 62, 174. French. 
15 Marat JP. L’Ami du peuple. 1793 Jan I4. p.5-7. French.

16 Vess DM. Medical revolution in France, 1789-1796. Gainesville: University Press of Florida; 1975. p.I7.

17 Saugera E. Bordeaux, Port Négrier: chronologie, économie, idéologie, XVIle-XIXe siècles. Biarritz: J\&D Editions; 1995. French.

18 i-anatomie.com [Internet]. Bordeaux: Laboratoire d'Anatomie MédicoChirurgicale Appliqué. L'Histoire de l'anatomie Bordelaise [cited 2012 Dec 18].Available from:http://www.i-anatomie.com/?content=lamca/ histoire.php\&univers $=3$

19 Weiner DB. The citizen-patient in revolutionary and imperial Paris. Baltimore and London:The Johns Hopkins University Press; 1993.

20 Silver JR, Weiner MF. Edward Harrison and the treatment of spinal deformities in the nineteenth century.J R Coll Physicians Edinb 2008; 38:265-7I.

21 Phipson SL. Jean Paul Marat: his career in England and France before the revolution. London: Methuen and Co Ltd; 1924. p.42-3.

22 Bynum WF. Treating the wages of sin: venereal disease and specialism in eighteenth century Britain. In: Bynum WF, Porter R Medical fringe and medical orthodoxy 1750-1850. London: Croom Helm; 1987.
23 Hunter J. Treatise on the venereal disease. 2nd ed. London: G Nicol and J Johnson; 1788.

24 Lind J. A treatise of the scurvy in three parts. Containing an inquiry into the nature, causes and cure of that disease, together with a critical and chronological view of what has been published on the subject. London: A Millar; 1753.

25 Marat in England. BMJ I893; I:305. http://dx.doi.org//0.II36/ bmj.I.I676.305

26 Marat JP. Les découvertes de M. Marat sur le feu, l'électricité et la lumière constatées par une suite d'expériences nouvelles. Paris: Clouiser; 1779. French.

27 Siegel PN. Review of Jean Paul Marat: Scientist and Revolutionary by Conner CD. New York: Humanity Books; 1999.

28 Lipman Cohen JH, Lipman Cohen E. Doctor Marat and his skin. Med Hist 1958; 2:28I-6. http://dx.doi.org/I0.I0I7/S002572730002398X

Royal College of Physicians of Edinburgh

\section{Writing a journal article}

Have you ever had a paper rejected for publication?

If so, have you ever wondered why it was rejected?

Would you like to improve your publication rate or the level of publication in which your papers appear?

The Writing a journal article course aims to assist RCPE Fellows, Collegiate Members and Associates, and their colleagues, in improving their publication rates through gaining a better understanding of what journals look for in submitted papers.

This course is designed for people who are at, or nearly at, the stage of putting together a paper for publication.

Writing a journal article provides valuable insights into how to plan, structure, develop and write a scientific paper; information on what editors and reviewers look for in papers; and original analyses of trends in medical publishing.

Next courses: Monday 4 March and Monday 7 October 2013

More information will be available in January on the

College website http://events.rcpe.ac.uk/

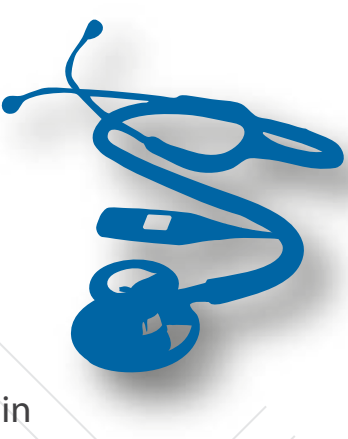

